\title{
THE DISTRIBUTION OF CONTROL IN SOME YUGOSLAV INDUSTRIAL ORGANIZATIONS AS PERCEIVED BY MEMBERS
}

\author{
Josip Zupanov and Arnold S. Thinnenbaly (1)
}

Organizations in all societies share common characteristics. 'I'hey all imply some form of concerted effort on the part of members and they all include a more or less stable pattern of authority relations designed to assure this coordinated behavior. However, the character of authority or control may vary widely among organizations, even among those that are similar in all other respects. These differences may reflect differences in formal plans or they may have evolved out of the particular circumstances within which the organizations function. The universality and centrality of control in organizations, however, suggest it as an important area for study and particularly as an aren within which comparative research might profitably be conducted.

Several models concerned with organizational control have been described in the literature (2). SMrth and TANNenbaum employing the control graph model have presented comparative data from over two hundred organizational units in the United States including business and industrial organizations, labor unions, and voluntary groups (3).

(1) This research is part of a more extensive program of studies undertaken by the Economics Institute of Zagreb concerning the behavior of the business firm. The present study was conducted under the direction of the first author who would like to thank the following persons who gave him their assistance: Dr. I. Kuvacic, Assistant Professor, Faculty of Philosophy, Department of Sociology, Zagreb University; Dr. P. NovoseL, Assistant Professor, Faculty of Political Sciences, Zagreb University; Mr. I. ZavrskI, the Workers' Univeraity of Zagreb; and Miss Cemalovic, the former Director of a department of the Workers' University where part of the survey was carried out. The second author provided consultation at an initial stage, and worked with the study director in interpreting the results and writing this paper. He would like to thank the Carnegie Corporation of New York, which, through a grant to the Survey Research Center, Institute for Social Research, the University of Michigan, permitted him to engage in this collaborative work. He would also like to thank the Tavistock Institute of Human Relations where he was in residence while part of this paper was being written. The authors appreciate the suggestions of Miso JEzEnNIK, although they alone are responsible for the interpretations presented in this paper.

(2) See e.g., Peter M. Bruv, Bureaucracy in Modern Society, New York: Random House, 1956; Michel Crozien, The Bureauctatic Phenomenon, London: Tavistock Publications, 1864; Amitai ETzIoN, A Comparative Analysis of Complex Organizations. Glencoe, Ill.: Free Press, 1061; Alvin W. GourDNER, Patterns of Industrial Bureaucracy. Glencoe, Ill.: Free Press, 1954; Rensis LIKert, New Patterns of Management. New York: McGrawHill, 1961; Max Weber, The Theory of Social and Economic Organization. A.R. HENDERson and Talcott Parson, translators. New York: Oxford Univ. Press, 1947.

(3) Clagett G. SMrTh and Amold S. TANNENBaum, “Organizational Control Structure: A Comparative Analysis," Human Relations, Vol. 16 (4), 1963, 299-316. See also, A. TaNNENBAUM, Control in Organizations. New York: MeGraw-Hill, 1968. 
'The present research is designed to extend this line of inquiry by attempting to ascertain whether the control graph method may be applicable in Yugoslavia. Are members of some lugoslav business and industrial organizations able to respond meaningfully to questions like those asked of mem. bers of American organizations about the distribution of control in their organizations? The present research is therefore exploratory and methodological in character. However, the data to be presented below seem reasonably encouraging from a methodological point of view and we are led to raise several questions of a more substantive, although entirely exploratory nature. How do members of some Yugoslav industrial firms perceive aspects of control in their organizations? How do these perceptions compare to the ideals which members express? How do supervisors and workers, Party members and non-members, differ in their perceptions and ideals regarding control? What meaningful comparisons can be made between these Yugoslav data and the American data presented by Smiтh and Tannenbaum? What possible implications do these data have for understanding the development and functioning of Yugoslav industrial organizations?

\section{1) General.}

\section{Rresf.lacil Sites A.sp Mrthon}

We cannot present here details of the social, political and legal factors relevant to un understanding of the Yugoslav industrial organization. The reader is referred to a number of books and articles which provide some background to this questions (4). We shall sketch a few of these factors briefly.

Prior to World War II Yugoslavia was largely an agricultural, peasant society. However, some industries existed. We shall describe the two most common (5):

First are industries organized as big handicraft shops with some elements of modern technology (such as large machines) but with no mass production. Skilled craftsmen were the center of the production process. Holding all basic functions, the skilled worker blocked the development of staff organization. These industries therefore had practically no staff. After World War II an attempt was made to improve these organizations largely through capital investments designed to enlarge plants and increase the number and sizes of

(4) The legal and institutional framework of the system of workers' self-management is thoroughly and accurately described in the B.I.T. study La Gestion Ouvriere des Entreprises en Yugoslavie, Geneve, 1962. See also Aser DELEoN, 33 Questions, 33 Answers on Workers' Self-Gooernment in Yugoslavia, Belgrade, Yugoslavia: Publicity Enterprise, 1956; and Oleg Mandic, Yugoslavia, in Arnold M. Rose (Ed.), The Institutions of Advanced Societies. Minneapolis: University of Minnesota Press, 1958. Social values and philosophies underlying the Yugoslav system of workers' councils are stated in the program of the League of Communists, Yugoslavia's Way-The Program of the League. New York: All Nations Press, 1958. For social studies see: Adolf Stcrmtral, Workers' Councils. Cambridge: Harvard University Presa, 1964; Jiri KolsuA, Workers' Councils, the Yugoslav Experience. London : Tavistock Publicstions, 1965; John T. DuNzop, Industrial Relations Systems. New York: Holt, 1959, Chapter 8. For general background information and views see George W. Horrmax and F.W. NEal, Yugoslavia and the New Communism. Fund for the Republie, 1902; Fitzroy Muctean, Tito. New York: Ballantine Books, 1957; and Charles P. Mcvicken, Titoism, Pattern for International Communism. London: Macmillan \& Co., Ltd., 1857.

(5) Ing. S. Nesek, Reoganizacija poduzeca radi poboljsamja odnosa prema radu i povecanja produkiivnosti rada. Ekonomske Jedinice $\boldsymbol{U}$ Praksi, Zagreb: Savezni Centar, 1901. 
machines. Some staff services which are characteristically found in modem industrial organizations were introduced, not without considerable resistance. However, the essential structure of the firms was not changed. Firms of this type can survive in modern times only in centralized economies where high production costs are permitted and where products can be sold at high fixed prices. The decentralization of the Yugoslav economy, which began with the strengthening of market forces as an important determinant of organitional survival, exerted pressure against the maintenance of this type of structure.

The second most important form of industry in pre-war Yugoslavia included branches of foreign companies some of which were engaged in montage. These were established largely as a means of overcoming customs obstacles. Parts were imported with low duty, were assembled into finished products and were sold domestically. These plants had great difficulty after the war because the montage function depended upon foreign parts. Now, however, some are producing their own parts and are managing to survive.

The character of authority differed somewhat in these enterprises. In the domestically owned, handicraft plants, the basis of authority was largely traditional. Industrial organizations inherited patterns of authority which had been part of the handicraft system of production established during feudal times. The authority relationship was essentially that of master to servant. Status distinctions and personal deference by subordinates toward supervisors were strongly emphasized. Within broad limits, decisions by managers were non-bureaucratic; they were personal, arbitrary and sometimes harsh.

Foreign owned plants did not usually have either a traditional or a legal rational basis of authority. Some foreign managements tried to establish legitimate control through paternalistic devices. Others, as in the coal mining industry, resorted to coercive techniques of control.

Plants organized as big handicraft shops were the most prevalent in the Zagreb area where most of the organizations included in this research are located. These handicraft shops set the stage for most new industry in this region. Persons from old plants of this type transferred to the new ones created after the war and they brought with them their old ideas and habits, including their traditional attitudes toward authority. These habits, however, were not in direct conflict with the post war nationalization. Nationalization simply brought centralization through special government agencies set up to manage business firms. The Party, and to some extent trade unions were employed as a means of expediting centralized control. Very little autonomy was given the business firm. Production plans, prices, distribution, and other business arrangements were fixed. This did not change the handicraft method of production with its rigid hierarchy, its traditional approach to authority and the important role of the craft worker. On the contrary, the old form was frozen.

In 19.50 the system of workers' self-management was introduced through a law passed by the Federal Parliament (6). This law had a number of important stipulations. The centralized agencies were disbanded and broad areas of policy-making authority were delegated to the workers' collectives (i.e., to all members of the firm). The government was thus deprived of its managerial function within firms. It did, however, exercise some important (or "regulating") control through taxation, dispensation of credit, regulations

(6) The following is a brief and simplified description. The reader should recognize that the system is in a state of flux. 
concerning imports and exports and general laws regarding the distribution of profits. While great authority was officially delegated to the workers' collectives, the control which plant managers could exercice was not lessened. On the contrary, plant managers now had greater freedom of action and were probably able, through their strategic position within the firm to exercise more control than formerly.

The 1950 law implied two authority structures within firms; one concerned with the determination of general policies including "basic" decisions like setting prices; and one concerned with technical, administrative and operative decisions including: 1) advising, consulting, and preparing proposals; 2) making subsidiary decisions in implementing approved policies; and 8) exercising management prerogatives given by law directly to managers, e.g., making business contracts and some personnel decisions.

Two related hierurchical axes might therefore be said to exist. They are joined at one end by the general manager who plays a role in both. The first includes workers as producers at one end, followed by supervisors, heads of economic units (which are roughly equivalent to department heads) and the manager at the other. The second includes the workers' council at one end, followed by the managing board and the manager at the other. Theoretically, the first is concerned with operative, and the second with general policy decisions.

Workers' councils and managing boards are elected bodies composed of the employees of an enterprise. The workers' council may include as many as 120 members depending upon the size of the enterprise. It meets at least once every six weeks. The managing board consists of three to eleven persons elected by the council but the general manager is a member by law. Prior to the 1950 law the function of the council was solely advisory, suggestive and consultative. Its function has subsequently been strengthened. The workers council is now delegated by law as the most authoritative of the three groups in the second hierarchy described above. "If one were to pose the question thus: who is senior-the workers' council, the managing board, or the director of an enterprise-in the sense of who was accountable to whom, then the answer would be that the workers' council was superior over the rest, since the director accounts to the managing board for his work and must abide by its decisions, while the managing board is accountable to the workers' council..." (7) The manager is formally appointed to his job by the workers' council. All other managers and supervisors are appointed by the managing board.

Economic units are a relatively recent innovation designed to expedite decentralization within the firm. They are functional groups, in many respects like socio-technical units (8) and organizational families (9). They may, however, include a number of supervisors and a larger number of workers than is typical of the organizational family. Economic units have, theoretically, a high degree of autonomy and a number of economic and social prerogatives such as deciding how wages and work might be distributed among members or whether a new worker should be permitted into the group.

(7) Delnon, op. cil.

(8) Eric L. Trist, Gurth W. Hrgain, Hugh Murray, and Alec B. Pollock, Organizational Choice, London: Tavistock Publications, 1963.

(9) LIKERT, op. cit. 


\section{2) Organizations and Workers Studied}

The respondents in the present study include 56 workers attending a two-year course at the Workers' University in Zagreb. They come from a number of Zagreb industries ranging in size from 200 to 10,000 members. They attend the university part time while working four hours a day. This group does not comprise a sample in the technical sense of the term. In includes a relatively high proportion of formally educated, highly skilled and aspiring workers. Approximately $89 \%$ hold membership in the Communist Party as compared to $10.6 \%$ of workers in the district of Zagreb (10). Thirtynine percent are first-line supervisors. This group includes members who are probably more aware of the processes of control than the average worker. Furthermore, being at a university and away from work part time, they may be in a better position psychologically to think about and answer freely questions about control in their organizations; they were probably in a "good" frame of mind as respondents for a study of this type. These respondents, then, comprise a special group.

Despite the special character of this "sample," the data to be presented below are similar in general ways to results obtained from questionnaires administered as pretests in several plants and to an earlier sample from the Workers' University. They are also consistent in large measure with results obtained from questionnaires in which variations in phraseology were tried. Furthermore, an independently conducted study in Slovenia and a recent investigation employing similar methods in Serbia. which we shall describe below, provide additional data within which the results of the present study can be interpreted (11). We therefore present these data as illustrative of those from a larger number of respondents in a variety of locations. Where our experience with these other "samples" suggests qualifications, these shall be indicated in our discussion of results.

\section{3) Questionnaire method}

Each respondent was given a paper-and-pencil questionnaire in which were included questions employed in connection with the control graph method. An attempt was made to use questions as close as possible in their meaning to those employed in American studies. These include questions concerning the amount of influence that various hierarchical groups in the organizations are perceived to have, as well as questions concerning the amount of influence these groups should have. For the sake of simplicity, the results of the former are referred to as "actual" control and the latter as "ideal" control. The questions were asked in tabular form as follows:

(10) Official data, 1958.

(11) For further research in Yugoslavia employing the method of the control graph see Veljko Rus, Status vodstoenega kadra o pogojih samoupravljanja, Kranj: Zavod za organizacijo de la v Kranju, 1964; and J. ZUPANov, Grafikon utjecaja kao analiticko orude za izucavanje struckturalne promjene socijalne organizacije podurecd, Zagreb: Ekonomski Institut, 1964. Unpublished doctoral dissertation, University of Ljubljana, 1964. 
How much influence do the following groups have on what happens in the firm :

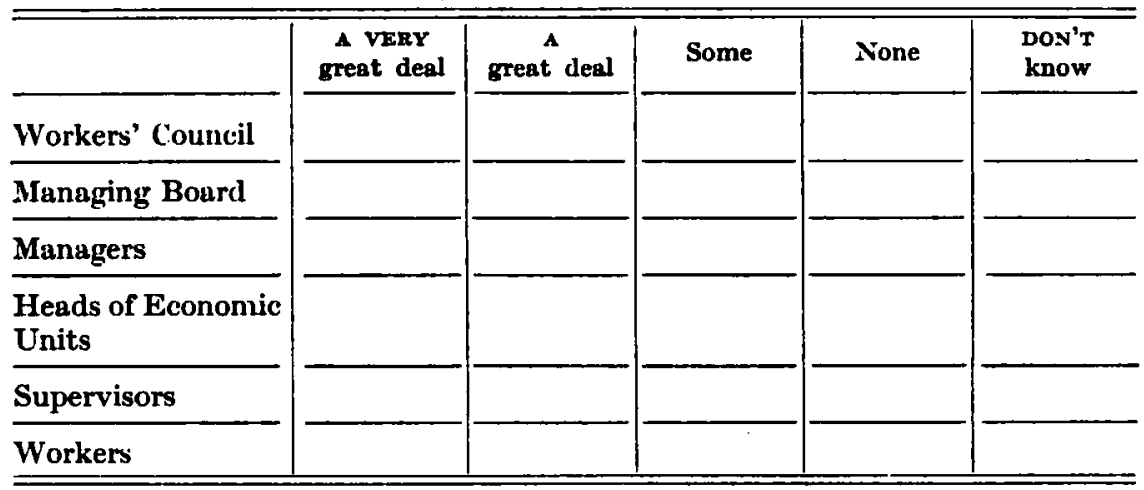

'Ihis is the "actual" control question. A second question in which the word "should" was substituted for "do" formed the "ideal" question.

In addition to these questions a series of parallel "actual" questions was asked concerning the following 13 areas of decision-making:

1. Approving annual production plan

2. Fixing prices

3. Investments (purchasing new machines)

t. Investments (building new shop)

5. Nllocation of the net profit

6. Use of funds for "collective consumption" (welfare, housing, cufeteria, etc.)

7. Wages and salaries

8. Assigning employees to jobs

9. Assigning particular tasks to enployees

11. Fixing work standards

11. Hiring

12. Firing

13. Disciplining enployees.

All respondents were questioned during class hours at the Workers' University. The questionnaires were strictly anonymous and all respondents were assured that their individual answers would be kept confidential. Respondents were told that the survey was designed for the purpose of gaining scientific knowledge. There is reason to think that most respondents accepted the good faith of the researchers although some of them may have been septical about the stated objectives and some workers may have been reticent to respond frankly to the questions. Some respondents of this type eliminated themselves by not responding. Approximately 5\% of the total of 56 respondents were eliminated in this way. The data themselves, as the reader will see below, seem to indicate a willingness on the part of many respondents to answer frankly.

\section{Results}

Figure 1 shows the control curves, "actual" and "ideal" distributed along the two hierarchies described above. Figure 1A shows curves for hierarchy one; Figure 1B for hierarchy two. Both "actual" curves are negatively sloped. Managers, in other words, are considered the most influential group 
followed by heads of economic units, supervisors and workers in hierarchy one and by the workers' council and managing board in hierarchy two. However, the difference between the managers and workers' council is very small in this sample and "actual" curve two tends to be flatter than one. Both "ideal" curves, on the other hand, tend to be positively sloped. In curve one the workers as a group are desired to be most influential, while in curve two it is the workers' council. The discrepancy between the "actual" and "ideal" curves along hierarchy two is relatively small compared to that of hierarchy one. The largest discrepancy between "ideal" and "actual" occurs for the workers as a group. The respondents clearly feel that the workers should have more control than they do. The managers are the only group among those cited above for which respondents feel a decrease in influence would be appropriate. Despite this decrease, the "ideal" curves tend to be higher on the average than the "actual." Respondents are more inclined to increase than to decrease the influence of most groups. These results are in a number of respects strikingly similar to those collected in American organizations, yet some important differences are apparent too, as we shall see below.

It is interesting to see that the workers' council is perceived to have a reasonably high degree of control and that the discrepancy between "actual" and "ideal" for this group is not as large as that for the workers as a group. 'The large discrepancy for the latter occurs despite the fact that the workers' council is elected by the workers and is comprised in large part of workers. 'Ihis discrepancy seems to suggest that the workers' council, as a representative of workers does not give workers a sense of control in their enterprises (12).

$A$ possible explanation for this breakdown is suggested by the data of

'IABLE 1.

Perceptions by Workers' University "Sample" of the Influence of Various Groups within the Workers' Council *

\begin{tabular}{|c|c|}
\hline Group & $\begin{array}{l}\text { INPLUENCE } \\
\left(N^{\prime} \mathbf{s}=\mathbf{5 0 - 5 3}\right)\end{array}$ \\
\hline Managers & 4.7 \\
\hline Staff & +.1 \\
\hline Heads of economic units & 3.4 \\
\hline Supervisors & 2.7 \\
\hline White collar & 2.7 \\
\hline Highly skilled workers & 2.5 \\
\hline Skilled workers & 2.2 \\
\hline Seni-skilled workers & 1.6 \\
\hline Unskilled laborers & 1.5 \\
\hline
\end{tabular}

(12) This discrepancy may be a more general problem for representative systems of co-management than advocates of such systems believe. Note, for example, a similar “breakdown” in a Norwegian enterprise: Fred E. EMregy, and Einar Tyonsnud, Industrial Democracy, London: Tavistock Publications, 1968. The general conception in Yugoslavia of workers' self-management is not limited to representative forms of worker participation. 'The shortcomings of a purely representative system are becoming apparent to political and administrative leaders in Yugoslavia and attempts are being made to supplement the purely representative system with more direct forms of participation. The system of economic units is one such approach. Vide infra.

- Question: “How much influence do the following groups have on what goes on in the workers' council?" Answera checked on a scale from I, "none" to 5, "a very great deal." 


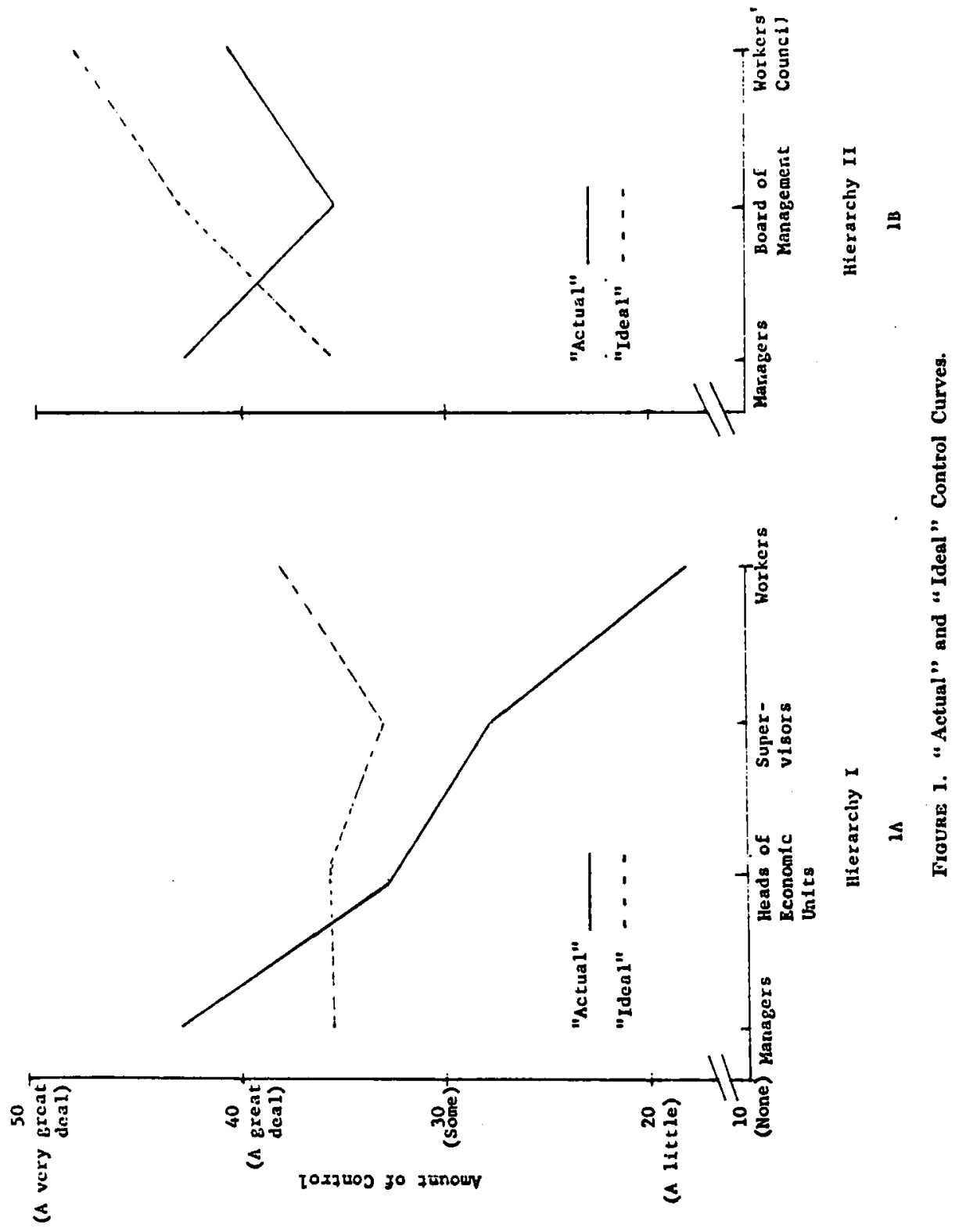


'Table 1. Here we see the influence which various groups in the enterprises have within the workers' councils as reported by our Workers' University sample. Workers' councils, according to these data, are influenced most by managers and relatively little by workers-although the councils are created expressly to represent the latter group. But differences among the various categories of workers are worth noting. White collar and skilled workers have more influence than laborers.

'This suggests that an educated and skilled work force is likely to provide conditions more favorable to the effective functioning of a workers' council system. 'Thus, while councils may be a means through which workers can exercise control, they need not be. Councils may, on the other hand, provide means through which managers and some other groups exercise control. One need not expect that high influence by the council of elected representatives necessurily will be felt as high influence by the electors themselves (13).

We did not ask questions about the influence of the Party or of trade unions within the organizations, although these groups unquestionably have influence too. The influence of trade unions, for example, is especially pertinent to the workers' councils since unions are usually important in choosing slates of candidates for election to the councils. The influence of the Party operates primarily through its members in the enterprise. The Party can exercise significant influence despite relatively low rates of membership since membership in the Party is more likely for persons at higher than for those at lower levels in the organization. Thus the influence of managers, who are very likely to be Party members, reflects to some extent influence of the Party. However, it would probably be incorrect to assume that Party influence throuth the manager or through other lines is absolute. The Party is only one among a number of sources of control over the enterprise. As an open system the organization is subject to many influences both internal and external.

The results concerning the 13 areas of decision-making provide an interesting comparison to the "global" results presented above. Managers are perceived to exercise more control than any other group in 12 of the 13 areas of decision-making. The exception occurs in the assignment of tasks to enployees where the head of the economic unit is perceived to be most influential, followed closely by supervisors.

Table 2 is an attempt to systematize some of the differences among control patterns in the 13 areas. These areas were chosen to fall roughly into two categories. The first seven rows in the table refer to areas of business policy; the remaining rows concern administrative issues. A plus sign signifies that the amount of influence by a hierarchical group (columns) in a particular area (rows) is above the median influence by that group in all areas. Thus we see in column 1 that the relatively great control which managers exercise is diversified among the two categories, policy and administration. This is consistent with the managers' roles in the two hierarchies, although one might question the advisability of managers concerning themselves to such a high degree with questions of hiring, disciplining and assigning employees to jobs. This appears to be a continuation by managers of their traditional approach to control. On the other hand, managing boards and workers' councils stress policy areas, while heads of economic units and supervisors exercise most of their control in administration. Tehse facts are consistent with the formal roles of these groups. The workers as a group, like the managers, have a

(13) See also, EMery and Thonsmud, ibid. 
TABle 2.

Amount of Control by Six Hierarchical Groups

which is above $(+)$ and below (-) Median

for the Respective Groups in Thirteen Areas

of Decision Making

\begin{tabular}{|c|c|c|c|c|c|c|c|}
\hline & \multicolumn{6}{|c|}{ HIERARCHICAI GROUPS } & \\
\hline & $\begin{array}{c}1 \\
\text { Mana- } \\
\text { gers }\end{array}$ & $\begin{array}{c}2 \\
\text { Board } \\
\text { of Mgt }\end{array}$ & $\begin{array}{c}\mathbf{3} \\
\text { Workers? } \\
\text { Council } \\
\end{array}$ & $\begin{array}{c}4 \\
\text { Heads of } \\
\text { Ec. Units }\end{array}$ & $\begin{array}{c}\text { 5 } \\
\text { Super- } \\
\text { visors }\end{array}$ & $\begin{array}{c}6 \\
\text { Workers }\end{array}$ & \\
\hline $\begin{array}{l}\text { 1) Approving annual } \\
\text { production plan }\end{array}$ & + & + & + & 一 & 一 & 一 & $\begin{array}{l}0 \\
\omega \\
\omega\end{array}$ \\
\hline 2) Fixing prices & - & + & + & - & 一 & - & 0 \\
\hline $\begin{array}{l}\text { 3) Purchasing new } \\
\text { machines }\end{array}$ & + & + & + & - & + & + & en \\
\hline 4) Building new shop & - & + & + & 一 & 一 & + & $\theta$ \\
\hline $\begin{array}{l}\text { 5) Allocation of net } \\
\text { profit }\end{array}$ & + & + & + & - & - & + & $i$ \\
\hline $\begin{array}{l}\text { 6) Use of funds for } \\
\text { collective c o n- } \\
\text { sumption }\end{array}$ & - & + & + & $\rightarrow$ & - & - & $\infty$ \\
\hline 7) Wages and salaries & + & + & + & + & + & + & \\
\hline $\begin{array}{l}\text { 8) Assigning em- } \\
\text { ployees to jobs }\end{array}$ & + & 一 & 一 & + & + & - & $\mathbf{z}$ \\
\hline $\begin{array}{l}\text { 8) Assigning tasks to } \\
\text { employees }\end{array}$ & 一 & - & - & + & + & + & $E$ \\
\hline $\begin{array}{l}\text { 10) Fixing work } \\
\text { standards }\end{array}$ & - & - & 一 & + & + & + & Ex \\
\hline 11) Hiring & + & 一 & - & + & - & 一 & 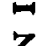 \\
\hline 12) Hiring & 一 & 一 & 一 & + & + & + & 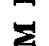 \\
\hline $\begin{array}{l}\text { 13) Disciplining } \\
\text { workers }\end{array}$ & + & 一 & - & + & + & - & 4 \\
\hline
\end{tabular}


more diversified pattern of inHuence although, as we have seen, their influence is relatively slight. $A l l$ groups exercise a relatively high degree of control over wage determination (item 7 ) and this is an area of obvious interest to all organization members.

Table 3 presents perceptions by supervisors and non-supervisors. Differences between these groups are not very great in the sample under investigation; there is a slight tendency for non-supervisory personnel to report greater control by all levels, but only the difference relative to heads of eco-

TABLe 3.

Distributions of "Actual" and "Ideal" Control as Reported by Supervisors and Non-Supervisors Workers' University "Sample," Zagreb

\begin{tabular}{|c|c|c|c|c|}
\hline \multirow{7}{*}{$\begin{array}{l}\text { Managers } \\
\text { Management board } \\
\text { Workers' council } \\
\text { Heads Econ. Units } \\
\text { Supervisors } \\
\text { Workers }\end{array}$} & \multicolumn{2}{|c|}{\begin{tabular}{cc}
\multicolumn{2}{c|}{ “ACTUAL" } \\
\multicolumn{2}{c}{ CONTROL } \\
PEREPTIONS BY: \\
supervisors & non-supervisors \\
$\left(\mathrm{N}^{\prime}=\mathbf{2 0 - 2 1 )}\right.$ & $\left(\mathrm{N}_{\mathrm{B}}=\mathbf{3 0 - 3 2 )}\right.$
\end{tabular}} & $\begin{array}{r}\text { “DEA } \\
\text { PERC } \\
\text { supervisors } \\
\left(N^{\prime} s=20-21\right) \\
\end{array}$ & $\begin{array}{l}\text { CONTROL } \\
\text { TIONS BY: } \\
\text { non-supervisors } \\
\text { (N': =31-33) }\end{array}$ \\
\hline & 4.2 & 4.4 & 3.6 & 3.6 \\
\hline & 3.4 & 8.6 & 4.3 & 4.4 \\
\hline & 3.7 & 3.9 & 4.8 & 5.0 \\
\hline & $3.0 *$ & 3.6 & 3.4 & 3.7 \\
\hline & 2.5 & 2.9 & 3.2 & 3.3 \\
\hline & 1.7 & 1.8 & 3.8 & 3.9 \\
\hline
\end{tabular}

* $\mathrm{p}<.05$

nomic units is found to be statistically significant $(p<.05)$. Similarly, differences in "ideals" expressed by the supervisory and non-supervisory respondents are slight and in the direction of greater control for most groups being proposed by non-supervisory employees. However, none of these differences prove significant statistically. By and large the patterns perceived and "desired" by supervisors and non-supervisors in this sample of respondents are quite similar. At the same time, differences between the "actual" and "ideal" distributions of control are strikingly different as reported by both groups. The absence of differences between supervisors and non-supervisors perhaps should be interpreted with special caution since these groups at the Workers' University may be more alike in education, skill, and other background characteristics than is ordinarily the case.

We can also take a look at differences between the perceptions of Party and non-Party members. We must, however, turn to a second "sample" in which sufficient numbers of Party and non-Party members are available to permit comparison (14). Data of this kind are available from a study of two departments; an old and a modern one, in a Serbian glass factory. The results of the comparisons in the new department (first half of Table 4) are similar to those between supervisors and non-supervisors (Table 3). Both Party and non-Party members report "oligarchic" distributions of control like those shown in Figure 1. Non-members, however, seem to report a slightly higher level of control by all levels, but none of the differences prove

(14) In the Workers' University sample, only 5 respondents are non-Party members. 


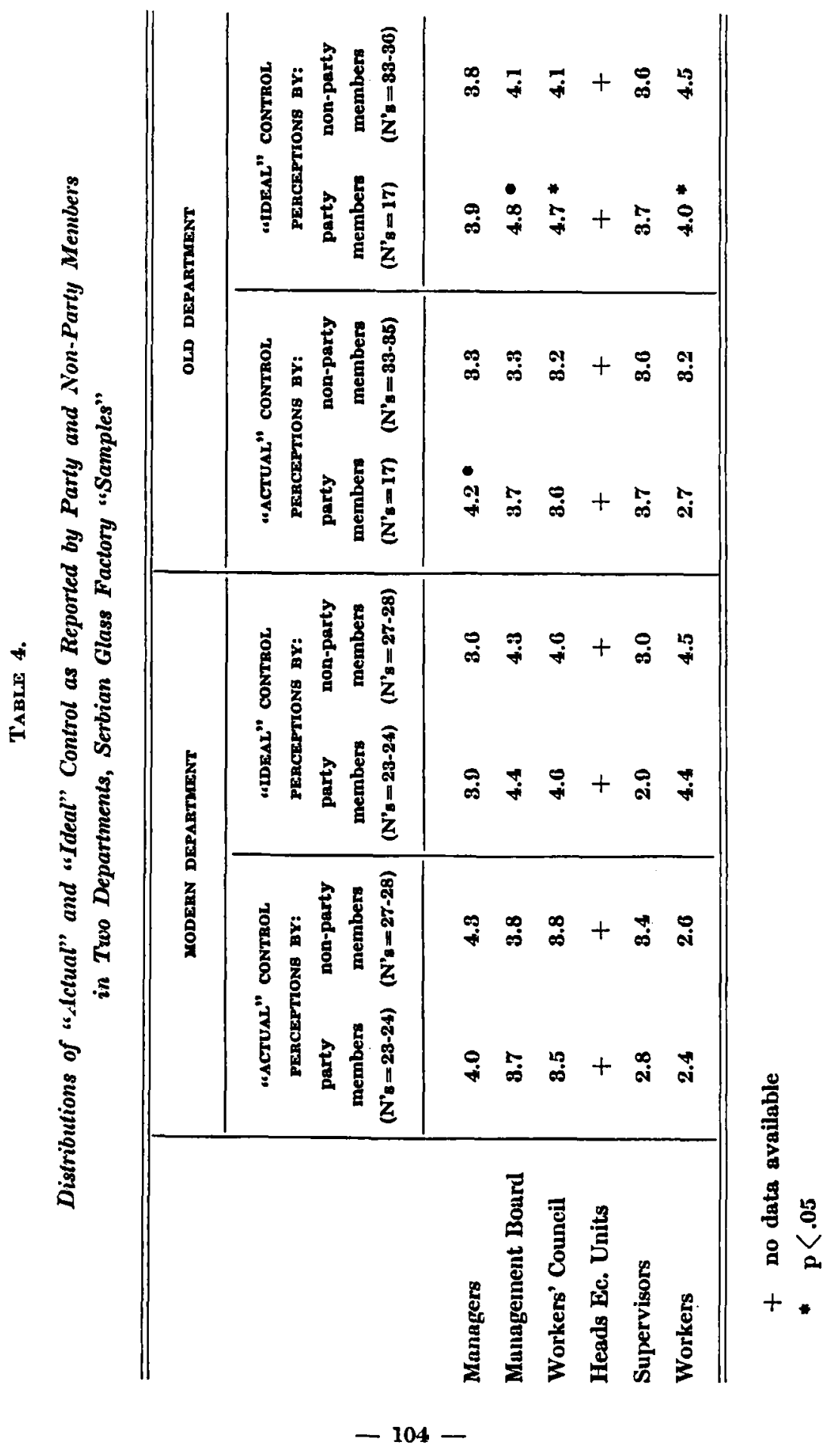


statistically significant $(p<.05)$. Again, the "ideal" distributions reported by our respondents, Party and non-Party members alike, are more positively sloped than the "actual" distributions. Differences between these two groups in their expressed "ideals" are minimal.

The results in the old department (second half of Table 4) differ in some respects from those already discussed. The discrepancies between Party and non-Party members in this department appear sharper than those between Party and non-Party members in the new department, and between supervisors and workers attending the Workers' University. We cannot be certain about the explanation for these discrepancies in the old department, although several facts about this department suggest themselves. The workers here are primarily glass blowers and blowers' helpers (as contrasted with machine operators in the modern department) who have learned their craft from their fathers in the traditional manner. The education level of these workers is lower than that in the new department-most are semi-literateand they probably do not have a background of experience which gives them an adequate basis for responding to our questions. Party members in this department on the other hand, are likely to have more formal education and they are therefore better able to respond to questions fo the type posed here. Furthermore, they are likely to be more perceptive about the distribution of control in the plant for, among other things, they tend more than nonParty members to have relationships with others outside the department. This is especially important in the old department which is relatively selfcontained and isolated. Non-Party members here are limited in their extradepartmental contacts and perceptions and they may not, for these reasons, be able to provide valid judgments about control. At the same time, it is worth noting that Party members in the old department do not offer a more presentable picture, politically, than non-Party members-quite the contrary. This contributes to our belief that Party members in the old department are not only more knowledgeable about the control pattern in the plant, but also that they are prepared to report their perceptions with reasonable frankness.

\section{Discussion}

\section{1) Methodological Implications}

The Workers' University respondents in this study are a select group. They have relatively high skills, education and aspirations. In all probability, a majority have been members of workers' councils and are reasonably knowledgeable about the processes of control in their plants. Most of them are therefore able to understand questions of the type posed here and they seem prepared furthermore to give meaningful answers. Some workers, however, especially those who have little formal education, are unable to answer these questions. This is apparent in the old department of the Serbian glass factory where a number of such persons were questioned (15). At the same time some respondents who are able to answer these questions may be reticent to do so or may answer in stereotyped ways.

The high proportion of Party members and of supervisors in our sample may raise questions about possible biases of our respondents and their likelihood to answer questions wishfully or to distort responses intentionally so as to present a more acceptable picture. However, the rough comparisons

(15) A survey in an industrial plant in Slovenis with a large proportion of skilled and educated workers proved more encouraging in this respect probably because the education level of workers and their sophistication about organizations is relatively high. Rus, op. cil. 
which are possible between Party and non-Party respondents and between supervisors and non-supervisors provide little support for this hypothesis -although we cannot reject it with certainty. The general character of the results, particularly the discrepancies between actual and ideal distributions, suggests that our respondents by and large answered the questions thoughtfully and frankly. In addition, our own observations of Yugoslav enterprises lead us to believe that the respondents, as a group, are providing a reasonably accurate picture of reality. Furthermore, the similarities between some of these data and those collected in the United States suggest that we are dealing with measures having some stability and which are concerned with important and fairly universal organizational phenomena.

\section{2) Yugoslav-American Comparisons}

We cannot know how well the data of this study apply to the Yugoslav industrial scene in general. Yet, consistencies within these data, and between these data and those collected in American organizations do provide a basis for the formulation of some tentative hypotheses that might be tested through further research. It is interesting to find for example, that the following quotation from the study by SMITh and TANIENBan of a large number of American organizations applies perfectly to our Yugoslav data:

A negatively sloped distribution of control occurs [in all of the industrial] organizational units studied. It is also apparent that the ideals which members have concerning the pattern of control differ from the actual pattern in almost all cases. The ideal distribution of control is more positively sloped than the actual and the ideal level of total control is higher than the actual level in a large percentage of the organizational units. While members desire a more positively sloped distribution of control than they perceive, they do not wish to achieve this by reducing the control exercised by other levels. They are more inclined to increase the control exercised by most groups, especially their own. (Members desire an increase in the control exercised by the rank-and-file group in 99 percent of the organizational units examined.) This results in a higher level of ideal than actual total control in most organizations. It also results in the actual curve approaching most closely that of the ideal near the upper levels of the organization. It is at the level of the rank-and-file member that the greatest discrepancy between actual and ideal control, as reported by members, occurs.

Some interesting differences are also apparent between the Yugoslav and American data. Ideal control is negatively sloped in all of the American industrial organizations studied (although less negatively than the "actual" distribution) but it is positively sloped in the Yugoslav organizations studied. This difference becomes amplified when supervisory respondents are considered along with non-supervisory. The supervisory groups studied in Yugoslavia indicate along with the workers a more positive "ideal" than "actual" slope. This is not true of the American data. Here officers indicate "ideal" distributions more positive than the "actual" in only $20 \%$ of the organizational units studied (16). Doubtless the political emphasis placed on workers' control

(16) SMrti and TANnenbaum, unpublished report. By way of contrast these authors report that officers in $97 \%$ of Leagues in the League of women Voters indicate "ideal" slopes more positive than the "actual;" Smith and Tannenbaum, op. cit. 
through the system of workers' self-management has an important effect on the responses of the Yugoslav supervisory personnel. On the other hand, the reluctance of supervisors in American industrial organizations to suggest more control for workers no doubt reflects the industrial relations climate in this society. Table 5 summarizes for purposes of comparison some of the characteristics of the Yugoslav and American data.

\section{3) Implications for the Functioning of the Yugoslav Enterprise}

The "ideal" curves illustrated in this research represent, at least in one respect, a pattern of control that has been found in several American studies to be associated with criteria of organizational effectiveness. The "ideal" tends to be more polyarchic, to represent a higher degree of total control than the "actual." Although it is not possible to develop on the basis of a few American studies principles that apply to industrial organizations in Yugoslavia, it seems a reasonable hypothesis that a realization of the ideal, more polyarchic pattern would be associated with an increase in organizational effectiveness. It is interesting in any event to find that the ideal, and more or less ideologically sanctioned distribution of control, conforms in certain important respects to what is found empirically in the United States to be associated with effective performance. It is interesting to find too, that, for whatever reasons, our respondents are taking a "constructive" approach to control. They see the desirability of change, but it is change in the direction of "more organization," not less.

The achievement of "more organization" in Yugoslav enterprises is beset with serious obstacles not least of which are the agricultural and to some extent, feudal traditions that have existed in this country. An industrial work force is only now being created. It is not by American or West European standards highly trained, educated, or sophisticated. One might expect that a system of workers' self-management would be more successful with a work force better equipped and more highly disposed toward it. However, the education level of the country will rise and this should contribute to a more sophisticated work force (17). In addition, workers' universities are providing training to limited numbers of workers which may help them better understand the technical, economic, and administrative problems of their organizations. These developments may in time provide better circumstances for the effective functioning of workers' self-management and for the movement of the "actual" curves closer to the "ideal." We have seen, for example, that skilled workers are likely to be more influential than unskilled.

The "economic unit" has been introduced into Yugoslav plants as one attempt to reduce the discrepancy between actual and ideal control. This functional unit with its prerogatives and autonomy was intended as a means for workers to exercise more direct control over some of the circumstances of their work lives. However, the immediate effect of this system, like that of workers' councils themselves, may have been to increase workers' aspirations regarding control, and hence to increase the "ideal" control by workers more than the "actual." A change in the latter may require more time.

An alternate approach to increasing control by workers was tried earlier by reducing some management prerogatives. This assumed that decreasing

(17) While the education level of the population as a whole is rising, that of the industrial work force is probably standing still at the moment. This is due to growth in industrialization and to the movement of poorly educated rural persons into factories. Education will probably catch up with the work force as this influx slows down. 
TabLi: 5.

Summary of Some Characteristics of Fugoslav and American Datn *

Sign of "actual" slope, hierarchy 1 perceived by workers pereeived by officers

Sign of "actual" slope, hierarchy 2 perceived by workers perceived by officers

Sign of "ideal" slope 1 perceived by workers perceived by officers

Sign of "ideal" slope 2 perceived by workers perceived by officers

"Ideal" slope 1 more positive than "actual"

perceived by workers

perceived by officers

"Ideal" slope 2 more positive than "actual"

perceived by workers

perceived by officers

"Ideal" total control 1 greater than "actual"

perceived by workers

perceived by officers

"Ideal" total control 2 greater than "actual"

perceived by workers

perceived by officers

"Actual" slope 1 perceived by officers more negative than "Actual" slope 1 perceived by workers

"Ideal" slope 1 reported by officers more negative than "ideal" slope 1 reported by workers

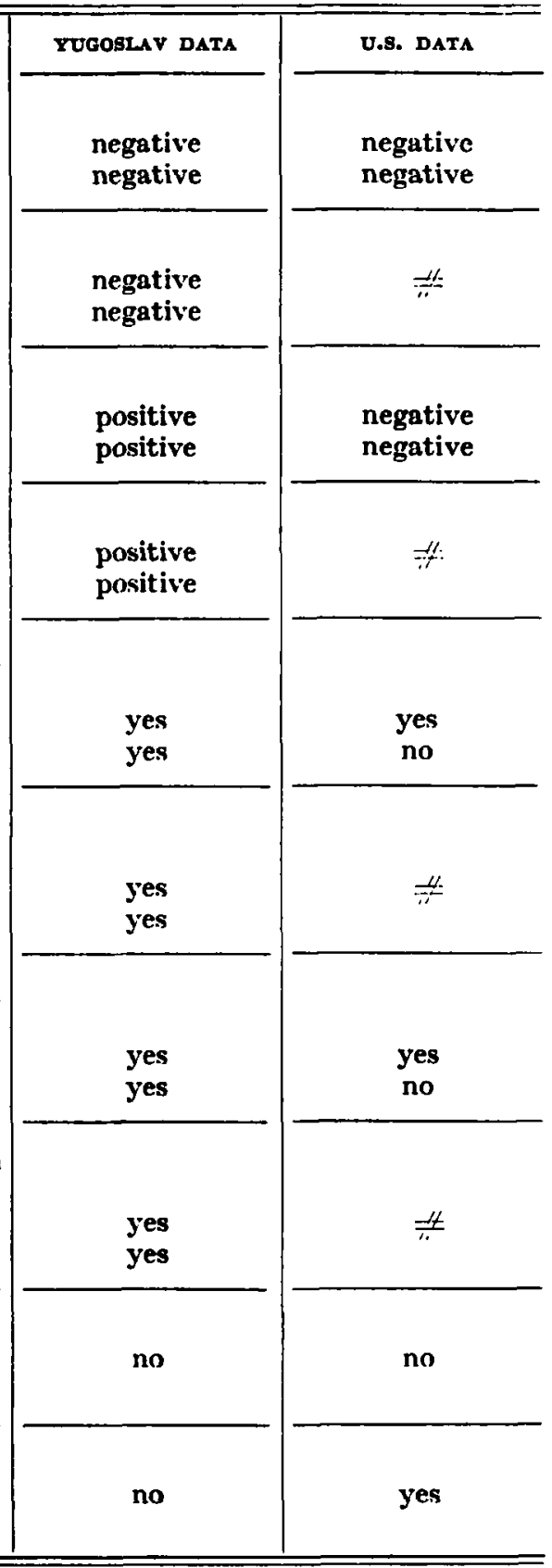

* U.S. date obtained from SMrtr and TANNENBaur, op. cit. and from an unpublished report by these authors. 'The general trends of the U.S. data are dichotomized in this table.

F No comparable data available. 
the control by managers would increase control by workers. Ilowever, this proved a mistaken assumption. Nonetheless, it is reasonable to think that some adjustment on the part of managers may be necessary in expediting greater control by workers. We have seen that managers comprise a crucial group in the Yugoslav enterprise. Our data also point to particular aspects of the manager's role, as he now plays it, that may represent an impediment to the development of a more polyarchic and effective system, and we would like to speculate briefly about this point.

Managers may not fully have accepted the redefinition of their functions that the new industrial system requires. Many managers are still playing to some extent the traditional role of "master," holding on to prerogatives of interpersonal control-hiring, disciplining, and assigning employees to jobs, that really should not be part of their job descriptions. These are administrative details that are best left to others. Managers might move in the direction of a more appropriate role definition that could include, first, greater concentration in the area of business policy rather than administration, opening up opportunities for subordinates to exercise control in the latter area. But this move might be extended by broadening, not reducing the scope of managerial power in the direction of what Selznick calls organizational statesmanship (18). Managers would think in broad value terms; in terms of the "mission" of their organization, of its long-range future and of its general impact in the larger society. Managers would devote themselves to problems of formulating general policy objectives and plans. They would help guide their organizations, as Selznick suggests, by embodying policy values into the structures of their organizations. This is a role quite different from that in which managers dissipate their energies disciplining workers. But it does not mean that managers are to be less influential-quite the contrary. It means extending the scope of management power and that of the organization itself into the community and into the larger society. It implies a more powerful organization externally and a more integrated polyarchic system within (10). This conversion of enterprises into "institutions," to use Selznick's term, or into "associations", to use a term in current usage in Yugoslavia, has implications for the character of the larger society as much as for organizations themselves. It implies a polycentric society in which its many institutions are important centers of power through which members can have influence extending beyond their immediate work lives (20).

(18) Philip Selznıck, Leadership in Administration. Evanston, Ill.: Row, Peterson and Co., 1957.

(19) The growth of internal organization power assumes a variable total amount of power or control in a system-although we recognize this as a controversial assumption. .The dominant tendency in the literature, for example, in LAswrell and Wright MiLLs, is to maintain explicitly or implictly that power is a zero-sum phenomenon, which is to say that there is a fixed quantity of power in any relational system and hence any gain of power on the part of $\mathrm{A}$ must by definition occur by diminishing the power at the disposal of other units B,C,D... There are, of course, restricted contexts in which this condition holds, but I shall argue that it does not hold for total systems of a sufficient level of complexity," 232-33, Talcott PArsons, “On the Concept of Political Power." Proc. Amer. Phil. Soc., Vol. 107 (3), 1963, 232-62. For a more detailed discussion of this point see A. Tannenbaux, Control in Organizations. New York: McGraw-Hill, 1068.

(20) This is consistent with the notion, expressed by some Yugoslav sociologists, that the system of workers self management is the central institution of Yugoslav society. Joze Goricsr, "Radnicko samoupravljanje kao drustvena institucija," Sociologija, No. 1, 1905, pp. 5-17. Paper presented at the symposium of the Yugoslav Sociological Association on Social Self Government, Split Feb. 11-13, 1905. 


\section{Concticsions}

The Yugoslav industrial scene is in a state of flux. New laws are being introduced which bear directly on the control structure of firms and workers, who are now only being introduced into industrial life, together with old hands, must adjust to these changing conditions. It seems a reasonable hypothesis that when the workers' council system was introduced fifteen years ago the discrepancies between the "ideal" (indicated in this paper) and the "actual" distributions (then existent) in the plants studied were greater than they are now because the "actual" distributions were more negative than they are now. Although it is impossible to document this interpretation within the framework of the present data, we probably see a reflection in them of some change in the direction of meeting the ideal.

However, the ideal still is beyond the actuality as our respondents and probably as most organization members see it. This is true particularly along the first hierarchy. This discrepancy between the ideal and the actual is attribuable in part to the rather "high" ideals expressed by our respondents. For example, discrepancies are smaller in the American industrial organizations studied, not because the "actual" curves are more positive in the latter, but rather because the "ideal" are more negative. These "high positive" ideals expressed in our data reflect new social values emerging in contemporary Yugoslavia. Although it is difficult to know how large a segment of the work force is represented by our "sample" it seems reasonable to think that it represents an important segment, and that many organization members are no doubt aware of these large discrepancies and feel some sense of disillusionment and frustration as a result. For example, one of the authors discussed with a clerical worker her dislike of the control distribution in her firm and particularly the relatively high control exercised by the manager. When it was suggested to her that managers might have relatively high influence in American plants too she replied: "Yes, but there's a difference. It was that way once here too, but we didn't claim to be a socialist society." The image of Yugoslavia as a socialist society probably has a bearing on the ideals and aspirations which organization members express regarding control.

The results of this study seem to us an encouraging first step in the development of research tools designed to measure a vital aspect of the functioning of Yugoslav organizations. Research of this kind can be extended to trace changes in the character of Yugoslav enterprises as they evolve from their present stage of development. This type of data can provide one index of the success of attempts to introduce and expedite workers' self-management. Further research on the relationship between perceived patterns of control and criteria of organizational effectiveness is also called for and we have reason to predict that some of the relationships found in American organizations will hold up in Yugoslav organizations too. We see this research not only as a means of acquiring some knowledge about the functioning of Yugoslav organizations, but as part of the process of broadening the basis for scientific generalization through research in widely differing cultures and political systems. 